Rapp. Gronlands geol. Unders. 48, 61-74 (1972)

\title{
THE GEOLOGY OF SOUTHERN JAMESON LAND
}

\author{
F. Surlyk and T. Birkelund
}

\section{Introduction}

In 1971 the mapping of southern Jameson Land was completed by four field parties (comprising the authors, K. Birkenmajer, J. H. Callomon, R. G. Bromley, Ulla Asgaard, Lise Alkærsig, B. Buchardt Larsen and S. R. Larsen). The work was a direct continuation of mapping along Hurry Inlet in 1970 (see Surlyk et al., 1971).

The Hurry Inlet area was the only part of southern Jameson Land well known from earlier investigations. Thus, Rosenkrantz (1929, 1934), Spath (1932), Harris (1937) and Callomon (1961) described the different parts of the sequence exposed in Neill Klinter, while Lower Cretaceous occurrences in south Jameson Land were known from the works of Aldinger (1935) and Spath (1947). The Triassic deposits, underlying the Kap Stewart Formation and referred to the Klitdal Formation by Rosenkrantz (1929), were investigated in detail by K. Birkenmajer during the 1971 season and compared to the lithological units of Scoresby Land. The results are given by Perch-Nielsen $e t$ al. (this report) and are therefore not dealt with here.

Before the 1971 season, the geology of the plateaux above Neill Klinter and the whole south-western part of the peninsula was totally unknown. This area revealed an unexpectedly complete Upper Jurassic-lowermost Cretaceous sequence. On the basis of fossil evidence this sequence can be correlated in great detail with the Upper Jurassic-Lower Cretaceous of Milne Land. Also the relationship between the sequence of southern Jameson Land and the Upper Jurassic of central Jameson Land, described by Birkelund et al. (1971), is now understood.

On the basis of our knowledge on the geology of the whole area formal lithological units can now be established for the full sequence (Surlyk et al., in press). Further, the boundaries of some of the earlier established formations are slightly revised and members, so far used in an informal way, are formalised.

Besides southern Jameson Land, the map (map 3) also covers the central part of the peninsula, mapped during the 1968-1971 field seasons. The eastern part of this area was earlier mapped by J. H. Callomon (Callomon, 1970). 


\section{Stratigraphy}

In the present report only the sediments of Rhaetic, Jurassic and Lower Cretaceous age are described. Detailed descriptions of the older sediments, mainly occuring in the eastern and northern parts of Jameson Land, are given by Perch-Nielsen $e t$ al. (this report \& in prep.).

The sequence is divided into 7 formations, the upper four of which are new. The six lower formations compose the Jameson Land Group. Definitions and detailed descriptions with type-sections of all the formations are given in Surlyk et al. (in press) and the present paper is therefore only to be considered a summary of the results.

In the following the formations and members are briefly described in ascending order.

\section{Kap Stewart Formation (Rosenkrantz 1929)}

The formation is dominated by loose or cross-bedded, coarse-grained, poorly sorted arkoses of whitish or greenish colour. The arkoses are interbedded with dark, silty shales and occasional thin coal seams. In the northern part of Jameson Land the formation is topped by a $20-30 \mathrm{~m}$ thick sequence of black barren shales. Plants (wood fragments, leaves and fruits) are well preserved in both the arkoses and the shales.

The thickness is about $170 \mathrm{~m}$ in southern Jameson Land and increases northwards to about $350 \mathrm{~m}$ at Antarctics Havn. The Kap Stewart Formation crops out along Neill Klinter at Hurry Inlet. The outcrop continues north along Klitdal and in northern Jameson Land the formation covers relatively large areas.

Harris (1937) dated the formation as Rhaetic-Lower Liassic on the basis of the flora.

\section{Neill Klinter Formation (Rosenkrantz 1929)}

The lithology is dominated by clean, poorly to well sorted quartz-mica sandstones with subordinate micaceous shales. However, fossiliferous arkosic sandstones (Rævekløft Member) occur at the base in the type area and thin conglomerates are locally intercalated at all levels. The sediments show a great variety of currentproduced structures such as cross-bedding, flaser structures, parting lineation and ripple marks.

The thickness increases from about $225 \mathrm{~m}$ in the type area to about $275 \mathrm{~m}$ in northern Jameson Land.

The formation crops out along the whole length of Neill Klinter and continues northwards where it covers relatively large areas in northern Jameson Land. It 
Table 4. The Jurassic-Cretaceous sequence of Jameson Land

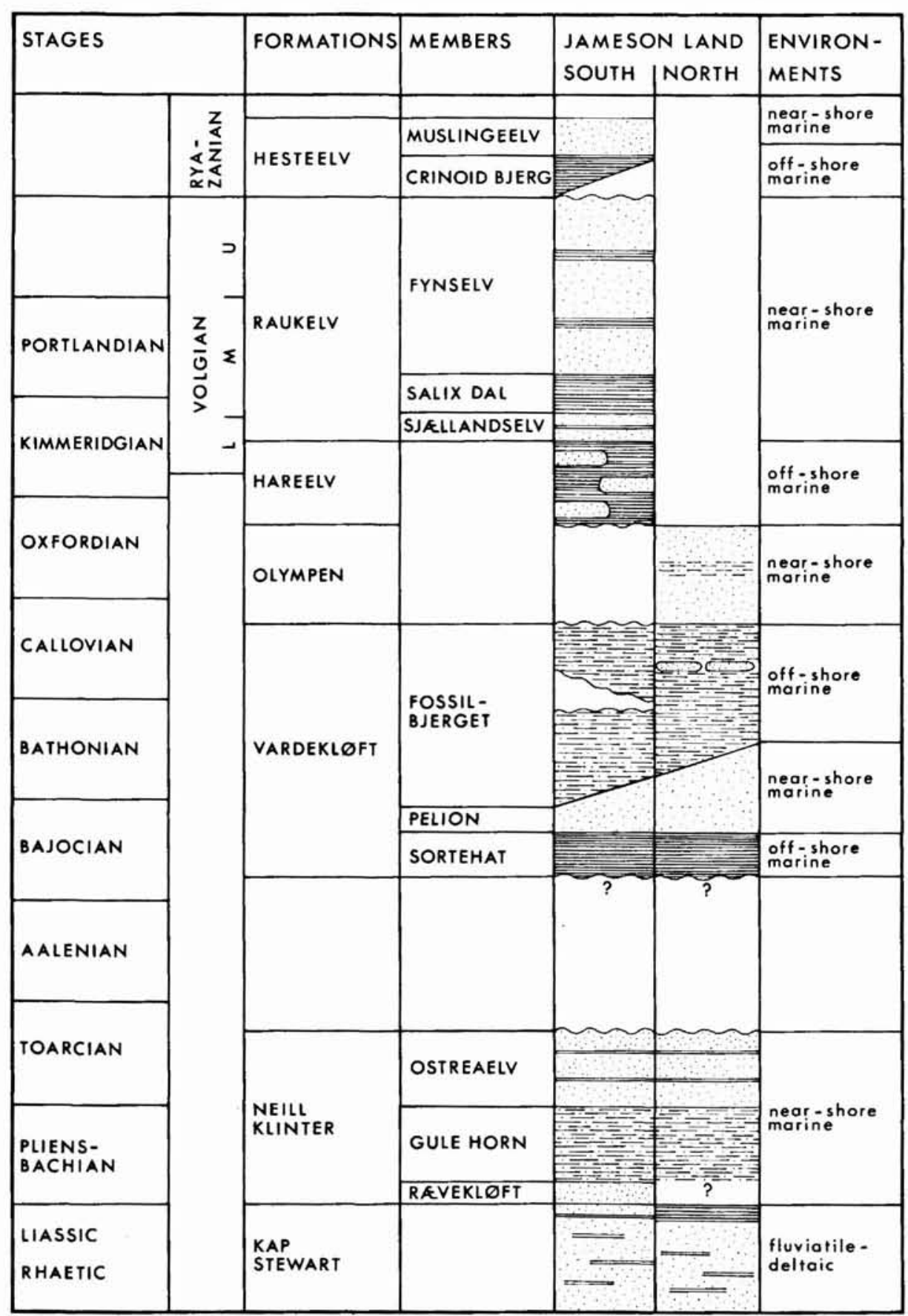


crops out in down-faulted areas at Antarctics Havn in Scoresby Land and at the south point of Liverpool Land.

The basal member of the formation contains a Lower Jurassic (Pliensbachian) fauna and the top member yields a fauna of Toarcian age (Rosenkrantz, 1934; Donovan, 1957).

The Neill Klinter Formation is divided into three members (Surlyk et al., in press).

2 a. Rævekløft Member (designated as new formal unit in Surlyk et al., in press.). In the type section the member is characterised by four prominent horizons of medium- to coarse-grained sandstones. The sandstones are grey, but weather to a reddish brown colour. Fossils are almost restricted to these four beds. The second concretionary sandstone horizon from the base is rich in feldspar grains and probably represents a reworking of the underlying arkosic sandstones of the Kap Stewart Formation. This bed contains a rich fauna which has been listed by Rosenkrantz (1934). It is characterised by pavements of Entolium. Feldspar is largely absent above this bed.

The second and third sandstone horizons thin out rapidly along the main part of Neill Klinter, and northwards to the head of Hurry Inlet the member is represented by a single massive sandstone bed.

In the western part of Jameson Land the member is found as lenses of fossiliferous arkosic sandstones.

The member has a thickness of $15 \mathrm{~m}$ in south Jameson Land but wedges out at the head of Hurry Inlet.

2 b. Gule Horn Member (designated as new formal unit in Surlyk et al., in press). The lower part of the member is dominated by a succession of thin-bedded, alternating quartz-sandstones and shales, both richly micaceous. The thin sandstones are ripple bedded, the upper surfaces with oscillation or linguoid ripple marks. At some horizons pure shales, flat-bedded sandstones and conglomerates of round quartz pebbles or pebbles of limonitic mudstone and shale fragments occur. Higher in the succession the shales become less important and quartz sandstones with thin conglomerates predominate.

The member thickens northwards from about $100 \mathrm{~m}$ at the head of Hurry Inlet to about $200 \mathrm{~m}$ in northern Jameson Land and is found in the same distributional area as the formation.

Fossils are almost completely lacking and none diagnostic of age has been found.

2 c. Ostreaelv Member (designated as new formal unit in Surlyk et al., in press). It comprises medium- to fine-grained quartz-sandstones. Many beds are strongly cross-bedded, erosional and laterally variable. Fossils occur at several horizons and rich faunas dominated by bivalves have been listed by Rosenkrantz (1934). 
The thickness is relatively constant at about $80 \mathrm{~m}$.

The Ostreaelv Member has the same distributional area as the formation. The member tends to produce wide plateaux and is well exposed over much of the area where the formation crops out in Jameson Land.

\section{Vardekloft Formation (Rosenkrantz, 1929)}

(upper boundary redefined in Surlyk et al., in press)

As the formation contains rich ammonite faunas, it has been dealt with by many authors. Earlier investigations are reviewed in Surlyk et al. (in press).

At Hurry Inlet the formation is represented by predominantly grey or black micaceous, silty shales with horizons of calcareous concretions. A thin sandstone intercalation in the middle part grows gradually thicker to the north. This light-coloured, sandy member, sandwiched between a lower and an upper shale member becomes dominant from central Jameson Land northwards.

The thickness rapidly increases from south to north, from about $100 \mathrm{~m}$ to $c .500$ $m$ in north central Jameson Land. The upper part is missing in northern Jameson Land and Scoresby Land as the formation forms the top of the plateaux here. At Antarctics Havn (the northernmost exposure in Scoresby Land) $550 \mathrm{~m}$ of the formation is preserved.

The Vardekløft Formation crops out in Neill Klinter at Hurry Inlet and in a down-faulted area at the south point of Liverpool Land. It covers large areas in central and northern Jameson Land, and in Scoresby Land it crops out in a downfaulted area at Antarctics Havn.

Both lower and upper boundaries of the Vardekløft Formation almost everywhere mark hiati in the sequence. The age of the lower member is uncertain. The middle and upper members range from Upper Bajocian (C. borealis Zone) to Callovian (E. coronatum Zone). The boundary between them is diachronous, rising to the north. Fossil evidence shows that the sequence is most complete in northern Jameson Land whereas important non-sequences occur at Hurry Inlet.

The Vardekløft Formation is subdivided into three members.

3 a. Sortehat Member (designated as new formal unit in Surlyk et al., in press).

The member is very uniform in the whole Jameson Land-Scoresby Land area. The lower part consists of dark grey to black shales with concretionary layers and nodules of claret-coloured ironstone. In the upper part the shales become more silty, the ironstone decreases or disappears and lenses or layers of fine sand, partly concretionary, appear in the sequence. The upper part may contain layers of calcareous concretions. The only fossils found are rare oysters and belemnites, and plant remains, especially wood.

The thickness of the Sortehat Member varies between 60 and $120 \mathrm{~m}$. The member has the same distributional area as the formation. 
3 b. Pelion Member (designated as new formal unit in Surlyk et al., in press). The Pelion Member is equivalent to the "Yellow Series" of previous authors (e.g. Callomon, 1970).

The member consists of medium- to coarse-grained, usually micaceous, light-coloured sandstones with subordinate intercalations of fine-grained sandstones and silty shales. Thin conglomeratic horizons occur locally. The sandstones are shaly, massive or cross-bedded and consolidated to varying degrees. The massive sandstones are usually barren, or contain scattered burrows, and are often terminated by a horizon with vertical U-burrows. The more shaly horizons may be fossiliferous, and isolated beds occur containing bivalves, belemnites and ammonites, sometimes in profusion.

Laterally the facies changes from slightly consolidated sandstones in the southern part of the area to often very well consolidated, massive, cliff-forming beds to the north. The thickness likewise increases from south to north: from $10 \mathrm{~m}$ or less at the southern end of Hurry Inlet, to $170 \mathrm{~m}$ at the head of Hurry Inlet, and more than $600 \mathrm{~m}$ at Antarctics Havn.

The member has the same distribution as the Vardekløft Formation in Jameson Land and Scoresby Land.

3 c. Fossilbjerget Member (designated as new formal unit in Surlyk et al., in press).

The member consists of silty, micaceous, non-argillaceous shales with subordinate fine-grained sandstone horizons. The lower part is more sandy than the upper part and contains glauconitic beds. Numerous horizons with phosphatic nodules, concretionary indurated silt or fine sand bodies ("doggers"), and calcareous concretions occur throughout. Many horizons are extremely fossiliferous, ammonites and belemnites being dominant. Fossil evidence shows that sedimentation was not continuous.

The thickness varies from 80 to $150 \mathrm{~m}$. The member crops out in Neill Klinter at Hurry Inlet and in central and northern Jameson Land. The northernmost localities are situated immediately north of the mountain Olympen.

\section{Olympen Formation}

(designated as new formal unit in Surlyk et al., in press)

The Olympen Formation corresponds in part to the now abandoned Koch Fjeld Formation (see Surlyk et al., in press). The formation can be divided into three lithological units (from below):

1) Medium-grained, light-coloured, well sorted sands and sandstones, intercalated with dark, silty shales. The thick sandstones are structureless or show large-scale cross-bedding. 
2) Dark, silty shales below passing upwards into gradually more sandy shales. The beds are poorly consolidated.

3) Massive, cliff-forming, medium- to coarse-grained, well sorted sandstones with subordinate shales. The sandstones are structureless or show large-scale crossbedding.

The full thickness of the Olympen Formation is not known, as the formation forms the top of the sequence in the whole of its distributional area, but it is at least $300 \mathrm{~m}$ thick at the northernmost localities.

Fossils are extremely rare. Unit 1 has yielded an Upper Callovian fauna (Birkelund et al., 1971). Unit 2 has yielded a single Lower Oxfordian Quenstedtoceras and unit 3 has yielded Middle Oxfordian Cardioceras (Birkelund et al., 1971).

\section{Hareelv Formation}

(designated as new formal unit in Surlyk et al., in press.)

The Hareelv Formation corresponds in part to the now abandoned Koch Fjeld Formation (see Surlyk et al., in press).

The formation consists of black and grey shales with large, irregular lenses and layers of yellow sandstone. The shales are soft, micaceous and often contain redbrown ferruginous concretions. The boundaries between the shales and the sandstones are always knife-sharp. The sandstone lenses may attain a length of several hundred metres and a thickness of $100 \mathrm{~m}$. The sandstones are well sorted and rich in mica, and sometimes in glauconite. Sedimentary structures are very rare in the massive sandstones. Ammonites and bivalves are common in the shales. In some of the harder glauconitic sandstone lenses small bivalves are found, but normally the massive sandstones are completely free of fossils.

The total thickness of the formation is not known precisely as both boundaries are rarely well exposed in the same section, but it seems to be $c .200 \mathrm{~m}$.

The Hareelv Formation is found in the southern half of Jameson Land where it forms the top bed over large areas.

In the basal shales of the formation a rich fauna of Upper Oxfordian ammonites is found. Higher parts have yielded ammonites indicating the presence of the whole of the Lower Kimmeridgian.

\section{Raukelv Formation}

(designated as new formal unit in Surlyk et al., in press).

The formation consists of cyclically alternating, thick, massive or large-scale crossbedded sandstone units and shaly siltstones. The sandstone horizons vary in thickness from 10 to $50 \mathrm{~m}$ and form conspicuous marker horizons. These sandstones characteristically produce a spectacular landscape of extensive plateaux dissected along joints to leave more or less isolated columns separated by deep, 


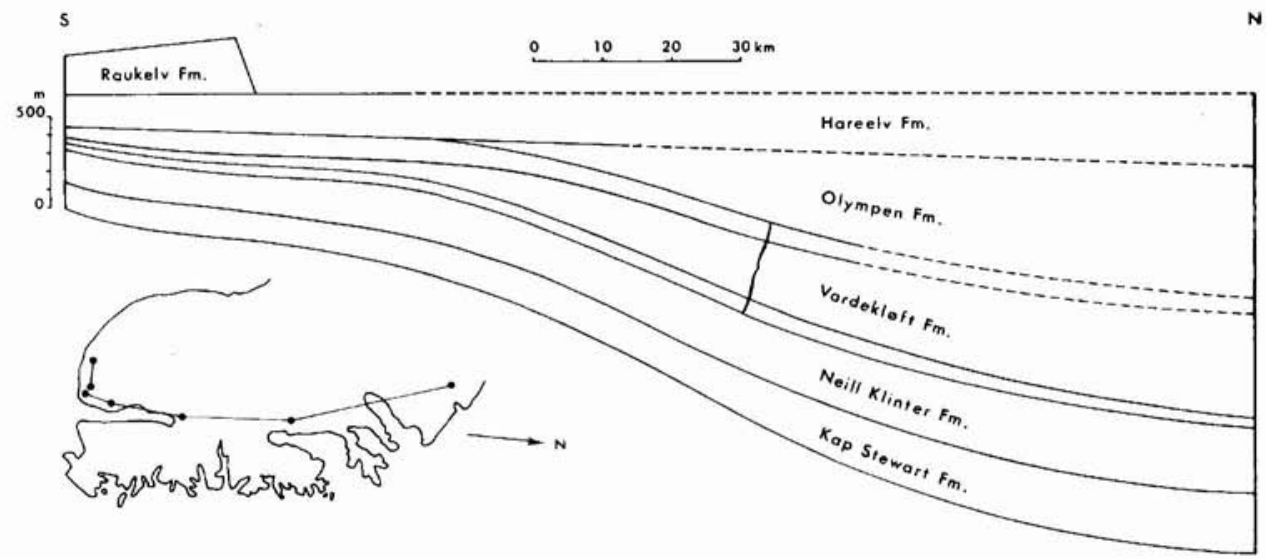

Fig. 9. Palinspastic N-S section of Jameson Land and Scoresby Land, showing the great subsidence of the northern part of the basin. The boundary between Hareelv and Raukelv Formations is used as a base-line. The position of the section is shown on the map. The short E-W line shows the position of the section on fig. 10 .

narrow clefts. The degree of sorting of the sandstones is very poor; the grain size is mainly in the coarse sand and gravel fraction. The sandstones are commonly massive or cross-bedded. In the basal part of the formation platy, red-brown sandstones with parting lineation or small-scale linguoid ripples often occur. From the air the cross-beds can be seen to form large concave fans with the concave side in the current direction. In the massive, coarse sandstones and gravels, ammonites, bivalves and crinoids are often found in great numbers. Between the sandstones occur thin horizons of brownish silty or sandy shales. They contain rare ammonites and bivalves, and occasionally large plant fragments.

The maximum thickness is estimated to be $300 \mathrm{~m}$ on the basis of several sections. The Raukelv Formation is found in the southernmost part of Jameson Land where it forms extensive plateaus.

The formation contains successive faunas of Upper Kimmeridgian-Upper Volgian age and is divided into three new members.

6 a. Sjællandselv Member (designated as new formal unit in Surlyk et al., in press).

Thick, massive and cross-bedded sandstones alternate with silty and sandy shales. Along the margins of the depositional area the cyclicity is only vaguely developed, but in the central part a sequence of three thick sandstone horizons alternating with shales can be followed over large areas.

The thickness varies between 100 and $200 \mathrm{~m}$. The distributional area is the same as for the formation. 
6 b. Salix Dal Member (designated as new formal unit in Surlyk et al., in press). Uniform, grey to black, micaceous silty shales with occasional calcareous concretions and a few thin layers of yellow sandstone make up the member. A thick, massive sandstone containing ammonites and bivalves is found half way up the succession in several localities. The member rapidly wedges out towards the south and east; the thickness is $0-70 \mathrm{~m}$. The member covers a rather large area in the western part of the distributional area of the formation.

6 c. Fynselv Member (designated as new formal unit in Surlyk et al., in press). Thick horizons of massive and cross-bedded sands and sandstones alternate with shaly siltstones and sandstones in a cyclical manner. In the major part of the area two sandstone horizans form conspicuous marker beds.

The thickness is approximately $130 \mathrm{~m}$. The member forms the top plateau of south central Jameson Land.

\section{Hesteelv Formation}

(designated as new formal unit in Surlyk et al., in press)

Sediments belonging to the Hesteelv Formation were described by Aldinger (1935). The fauna collected by Aldinger was described by Spath (1947).

The sediments of the Hesteelv Formation fill a small synclinal trough formed in the older rocks in southernmost Jameson Land. The axis of the syncline dips gently towards the south. The central parts of the depression are filled with black shales which pass upwards into silty and sandy, micaceous, somewhat irregular shales. The shaly sequence is terminated by a sandy shell-conglomerate which in the marginal parts of the trough lies directly on the sediments of the Jurassic Raukelv Formation. In the central parts the shell-conglomerate is overlain by a thin sequence of shale, wich again is topped by coarse sandstones.

The thickness varies between 10 and $120 \mathrm{~m}$. The formation is restricted to a small area in southernmost Jameson Land.

The age of the formation is Lower Cretaceous (Ryazanian). The formation is divided into two members.

7 a. Crinoid Bjerg Member (designated as new formal unit in Surlyk et al., in press).

In the southern part of the synclinal trough mentioned above the Crinoid Bjerg Member is developed as uniform black shales. Upwards and towards the margins of the trough the shales become more sandy and are characteristically developed as light brownish, irregular, silty and fine sandy shale. Further upwards, the shales grade into grey-brown, fine-grained sandstones with parting lineation and linguoid ripples.

The thickness of the Crinoid Bjerg Member is $0-85 \mathrm{~m}$. The member is found in 
the major part of the distributional area of the formation, but has wedged out at the northern and easternmost localities (fig. 10).

$7 \mathrm{~b}$. Muslingeelv Member (designated as new formal unit in Surlyk et al., in press).

The member commences with a very characteristic sandy shell-conglomerate which can be traced as a marker horizon in the central part of the area. The fossil assemblage is dominated by large thick-shelled bivalves with subordinate ammonites and belemnites. The shell-conglomerate is followed by massive or crossbedded light-coloured sandstones, and in the central part of the area by a thin sequence of brownish micaceous shale of the same type as the shales characteristic of the Crinoid Bjerg Member. These shales are overlain by massive or large-scale cross-bedded sandstones with vertical burrows, corroded and covered by a thin ferruginous crust. Perfectly spherical concretions varying in size from a few $\mathrm{mm}$ to $0.5 \mathrm{~m}$ are very common at many horizons.

The thickness of the Muslingeelv Member is $10-35 \mathrm{~m}$, but the original thickness is not known as the member comprises the youngest sediments of Jameson Land.

The distributional area is the same as for the formation.

\section{Structure}

In pre-Triassic time a vast peneplane was formed in the crystalline rocks of Liverpool Land (see also Rosenkrantz, 1934; Aldinger, 1935). The sediments of the

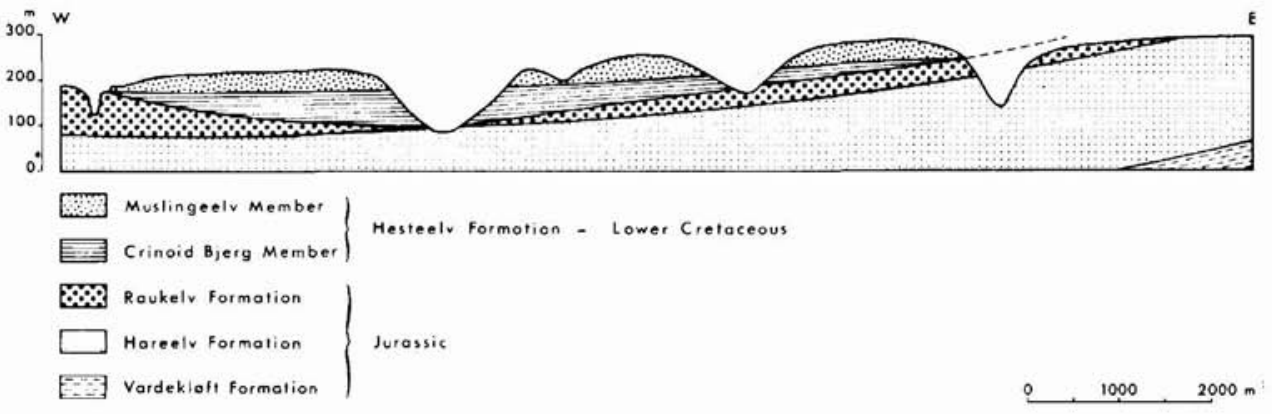

Fig. 10. E-W section of the Cretaceous basin in southernmost Jameson Land. The Lower Cretaceous rests with angular unconformity on slightly folded Jurassic strata. The Raukelv Formation wedges out towards the south. The thinning of the formation in the middle part of the section is therefore only to a small degree due to pre-Cretaceous erosion. The position of the section is shown in fig. 9. 


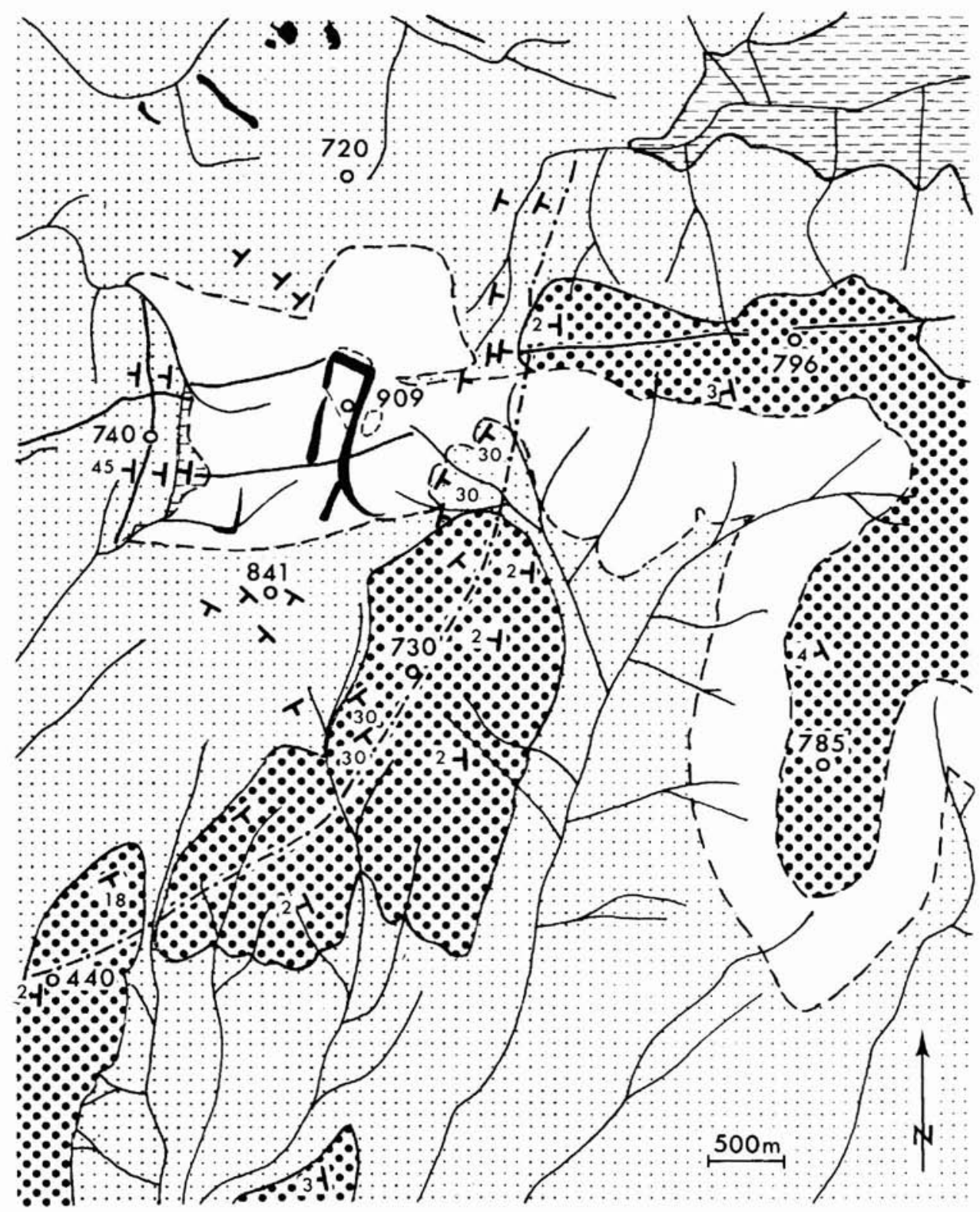

Fig. 11. Geological sketch-map of the J. P. Koch Fjeld area, showing the concentrically arranged disturbances around the mountain. The interrupted dotted lines indicate the trace of the axial planes of the southern and eastern monoclinal folds. The signatures are as given in fig. 10. Black indicates dolerite sills and dykes, and white areas covered by scree. On the summit of the mountain thin sandstones containing a few ammonites of preserved Valanginian age are found, but the age relations of these sediments cannot be determined with certainty. 
Jameson Land basin are deposited directly on the basement rocks or on Upper Palaeozoic (Devonian?) deposits, and no evidence for a fault-controlled contact as postulated by Coe (1970) has been found. In 1942 Rosenkrantz had already noted a sedimentary contact between Triassic sediments and basement in the downfaulted area at the south coast of Liverpool Land. Mapping of the boundary in Klitdal between the Jameson Land sediments and the crystalline rocks of Liverpool Land by Birkenmajer in 1971 revealed that the contact was everywhere sedimentary.

In Triassic time continental arkoses were deposited on the peneplane. In Lower Jurassic time the area was transgressed by the sea and marine conditions prevailed during the main part of the Jurassic, interrupted by periods of non-deposition or erosion. The greatest subsidence occurred in northern Jameson Land close to Carlsberg Fjord, whereas the succession thins markedly towards the south, where off-shore marine deposits are found (fig. 9). Throughout the period the transport direction is from NE-N-NW with a partly lateral, partly longitudinal basin filling.

In late Jurassic or earliest Cretaceous time the southernmost part of Jameson Land was folded into a shallow syncline, which became filled with marine Lower Cretaceous deposits (fig. 10). The break in sedimentation was very short.

An uplift of Liverpool Land and of the region north of Jameson Land was followed by a tilting of the Jameson Land sediments in a SSW direction and by the formation of a flexure along Hurry Inlet. The hinge-line of the flexure trends $\mathrm{N}-\mathrm{S}$ and is situated $5-10 \mathrm{~km}$ west of the Hurry Inlet coast. East of this line the dip is up to $13^{\circ}$ in a WSW direction, whereas the dip west of the line rarely exceeds a few degrees in a SSW direction.

In southernmost Jameson Land small-scale block-faulting followed by low-angle tilting is often found, but due to bad exposures the individual blocks cannot be deliminated with certainty.

At J. P. Koch Fjeld the sediments are disturbed and folded into a system of low monoclinal folds arranged concentrically around the summit of the mountain (see fig. 11). The disturbances are probably caused by the intrusion of a basalt plug.

The erosion caused by the rejuvenation of the Liverpool Land crystallines resulted in a total removal of the sedimentary cover of Liverpool Land.

The uplift and tilting was followed by intrusion of Tertiary dolerite dykes and sills.

\section{Tertiary dolerites}

The Tertiary dykes are characteristic morphological features in southern Jameson Land. Along the western coast of Hurry Inlet in Neill Klinter several sills are intruded in shaly siltstones of the Neill Klinter Formation. In many cases the sills are discordant, either gradually, cutting strata at a low angle, or abruptly. In places, 
pairs of sills are seen to be connected by a vertical dyke (see Rosenkrantz, 1934). In higher parts of the succession exposed in the interior of Jameson Land sills are relatively rare. At several localities (e. g. the summit of J. P. Koch Fjeld, fig. 11) the transgressive parts of sills are exposed as low-angle sheets of basalt. In southernmost Jameson Land an E-W to ESE-WNW swarm of dykes follows rather precisely the trend of the coastline. The dykes can often be traced across the whole of Jameson Land but are usually only a few metres thick, and are therefore not drawn to scale on the map.

In the central part of the area covered by the map, both dykes and sills are rare. The number increases again northwards in the direction of the Tertiary intrusive complex of the Werner Bjerge (see Perch-Nielsen et al., this report).

\section{References}

Aldinger, H. 1935: Geologische Beobachtungen im Oberen Jura des Scoresbysundes (Ostgrönland). Meddr Grønland 99, 1, 128 pp.

Birkelund, T., Håkansson, E. \& Surlyk, F. 1971: New finds of Bathonian, Callovian, and Oxfordian ammonites in northern Jameson Land, East Greenland. Bull. geol. Soc. Denmark 20, 240-259.

Callomon, J. H. 1961: The Jurassic System in East Greenland. In Raasch, G. O. (editor): Geology of the Arctic 1, 258-268. Toronto U. P.

Callomon, J.H. 1970: Geological map of Carlsberg Fjord - Fossilbjerget area. Meddr Gronland $168,4,10 \mathrm{pp}$.

Coe, E. 1971: Faulting in the western part of Liverpool Land, East Greenland. Bull. geol. Soc. Denmark 20, 260-264.

Donovan, D. T. 1957: The Jurassic and Cretaceous Systems in East Greenland. Meddr Gronland 115, 4, $214 \mathrm{pp}$.

Harris, T. M. 1937: The fossil flora of Scoresby Sound, East Greenland. 5: Stratigraphic relations of the plant beds. Meddr Gronland 112, 2, $114 \mathrm{pp}$.

Perch-Nielsen, K., Birkenmajer, K., Birkelund, T. \& Aellen, M., in prep.: Revision of Triassic stratigraphy of the Scoresby Land and Jameson Land region, East Greenland.

Rosenkrantz, A. 1929: Preliminary account of the geology of the Scoresby Sound district. In Koch, L.: I. The geology of East Greenland. Meddr Gronland 73, 2, 133-154.

Rosenkrantz, A. 1934: The Lower Jurassic rocks of East Greenland. Part I. Meddr Gronland $110,1,120 \mathrm{pp}$.

Rosenkrantz, A. 1942: The Lower Jurassic rocks of East Greenland. Part II. The Mesozoic sediments of the Kap Hope area southern Liverpool Land. Meddr Gronland 110, 2, 56 pp.

Spath, L.F. 1932: The invertebrate faunas of the Bathonian-Callovian deposits of Jameson Land (East Greenland). Meddr Gronland 87, 7, 158 pp.

Spath, L. F. 1947: Additional observations on the invertebrates ((chiefly ammonites) of the Jurassic and Cretaceous of East Greenland. I. The Hectoroceras fauna of S. W. Jameson Land. Meddr Gronland 132, 3, 70 pp.

Surlyk, F., Bromley, R. G., Asgaard, U. \& Petersen, K. R. 1971: Preliminary account of the mapping of the Mesozoic formations of south-east Jameson Land. Rapp. Gronlands geol. Unders. 37, 24-32. 
Surlyk, F., Callomon, J.H., Bromley, R. \& Birkelund, T., in press: Stratigraphy of the Jurassic - Lower Cretaceous sediments of Jameson Land and Scoresby Land, East Greenland. Bull. Gronlands geol. Unders. (also Meddr Gronland). 